\title{
Raf acts downstream of the EGF receptor to determine dorsoventral polarity during Drosophila oogenesis
}

\author{
Andrea H. Brand ${ }^{1,3}$ and Norbert Perrimon ${ }^{1,2}$ \\ ${ }^{1}$ Department of Genetics and ${ }^{2}$ Howard Hughes Medical Institute, Harvard Medical School, \\ Boston, Massachusetts 02115 USA
}

\begin{abstract}
In Drosophila, as in mammalian cells, the Raf serine/threonine kinase appears to act as a common transducer of signals from several different receptor tyrosine kinases. We describe a new role for Raf in Drosophila development, showing that Raf acts in the somatic follicle cells to specify the dorsoventral polarity of the egg. Targeted expression of activated $\operatorname{Raf}\left(\mathbf{R a f}^{\mathrm{gof}}\right)$ within follicle cells is sufficient to dorsalize both the eggshell and the embryo, whereas reduced Raf activity ventralizes the eggshell. We show that Raf functions downstream of the EGF receptor to instruct the dorsal follicle cell fate. In this assay, human and Drosophila Raf ${ }^{\text {gof }}$ are functionally similar, in that either can induce ventral follicle cells to assume a dorsal fate.
\end{abstract}

[Key Words: Raf serine; threonine kinase; oogenesis; dorsoventral signaling]

Received November 11, 1993; revised version accepted December 23, 1993.

The Drosophila ovary is made up of $\sim 16$ ovarioles, each consisting of a series of egg chambers (King 1970; Mahowald and Kambysellis 1980), that have been subdivided into 14 distinct stages (King 1970). Until mid-oogenesis, the egg chamber is fairly symmetrical with respect to the dorsoventral position of the oocyte nucleus and to the shape of the overlaying follicle cells. During stage $8 / 9$, the oocyte nucleus migrates to the prospective dorsal side of the oocyte, and subsequently, the dorsal follicle cells become more columnar and tightly packed. The follicle cells eventually secrete the eggshell or chorion, which is itself asymmetric as indicated most clearly by the presence on the anterodorsal side of the dorsal appendages.

The dorsoventral polarity of the Drosophila egg is established by means of signaling between the germ linederived oocyte and the surrounding somatic follicle cells (Schupbach 1987; Schupbach et al. 1991). The current model (e.g., see Schupbach et al. 1991) postulates that an asymmetric signal, from the oocyte, instructs the follicle cells nearest the oocyte nucleus to assume a dorsal fate. The follicle cells, in turn, establish the dorsoventral polarity of the developing embryo by restricting the activation of a ligand to the ventral side of the embryo, where it specifies embryonic dorsoventral polarity (Schupbach 1987; Manseau and Schupbach 1989; Stein et al. 1991; Stein and Nusslein-Volhard 1992).

Of the maternal effect genes involved in dorsoventral

${ }^{3}$ Present address: The Wellcome/CRC Institute and Department of Genetics, University of Cambridge, Cambridge, CB2 1QR, England. signal transduction, gurken is most likely to encode the dorsal signal (Schupbach 1987; Neuman-Silberberg and Schupbach 1993): the gurken transcript is localized asymmetrically, concentrating in the anterodorsal region of the oocyte. Furthermore, gurken has been shown to encode a TGF- $\alpha$ homolog, lending further support to its potential role as a ligand. $f s(1) K 10$, spire, cappuccino, and squid (Wieschaus et al. 1978; Prost et al. 1988; Manseau and Schupbach 1989; Kelley 1993) act to confine the signal to the dorsal side of the oocyte (NeumanSilberberg and Schupbach 1993). The Drosophila epidermal growth factor (EGF) receptor homolog, encoded by torpedo or DER (Price et al. 1989; Schejter and Shilo 1989), is required in the follicle cells to receive the signal from the oocyte (Schupbach 1987; Clifford and Schupbach 1989; Schupbach et al. 1991). In addition, a putative transmembrane protein, encoded by the gene rhomboid, may potentiate the interaction between the EGF receptor and its ligand (Ruohola-Baker et al. 1993).

$D E R$ not only specifies the dorsal follicle cell fate, but also determines the dorsoventral axis of the developing embryo. On the ventral side of the egg chamber, a signaling cascade is initiated that culminates in the localized activation of the Toll receptor in the embryo after fertilization (Anderson et al. 1985; Hashimoto et al. 1988, 1991; Stein et al. 1991; Chasan et al. 1992; Stein and Nusslein-Volhard 1992). Activating DER within the dorsal follicle cells may block production of an active ligand for Toll, and in so doing specify the dorsal side of the embryo.

Here we demonstrate a role for the Raf serine/threonine kinase in establishing dorsoventral polarity during 
oogenesis. Raf has been implicated in at least two different signal transduction pathways in Drosophila: $(1)$ in relaying signals from the torso receptor tyrosine kinase (RTK) to determine cell fates at the embryonic termini (Ambrosio et al. 1989a,b) and (2) in signaling from the sevenless RTK to specify the fate of the R7 photoreceptor cell in the developing eye (Dickson et al. 1992). Activating torso or sevenless initiates a signaling cascade that results in the activation of Ras1, possibly by repressing Gap1 (a Ras GTPase-activating protein) and stimulating Sos (a guanine nucleotide exchange factor) (Rogge et al. 1991; Simon et al. 1991; Dickson et al. 1992; Fortini et al. 1992; Gaul et al. 1992; Lu et al. 1993; Doyle and Bishop 1993|. Ras in turn activates Raf that, in the terminal pathway, appears to activate the mitogen-associated protein (MAP) kinase activator, MAP kinase kinase, or MAPK/ERK Kinase (MEK) (Tsuda et al. 1993).

Using targeted expression, we show that Raf functions downstream of the EGF receptor to transduce the germline signal that specifies the dorsal follicle cell fate and establishes the dorsoventral polarity of the developing embryo. We have expressed activated Raf (Raf ${ }^{\text {gof }}$ ) within follicle cells, and demonstrate that ectopic activation is sufficient to dorsalize both the egg shell and the embryo. Conversely, reduced Raf activity is shown to ventralize the eggshell. We demonstrate that human and Drosophila Raf ${ }^{\text {gof }}$ are functionally similar, in that either can induce ventral follicle cells to assume a dorsal fate.
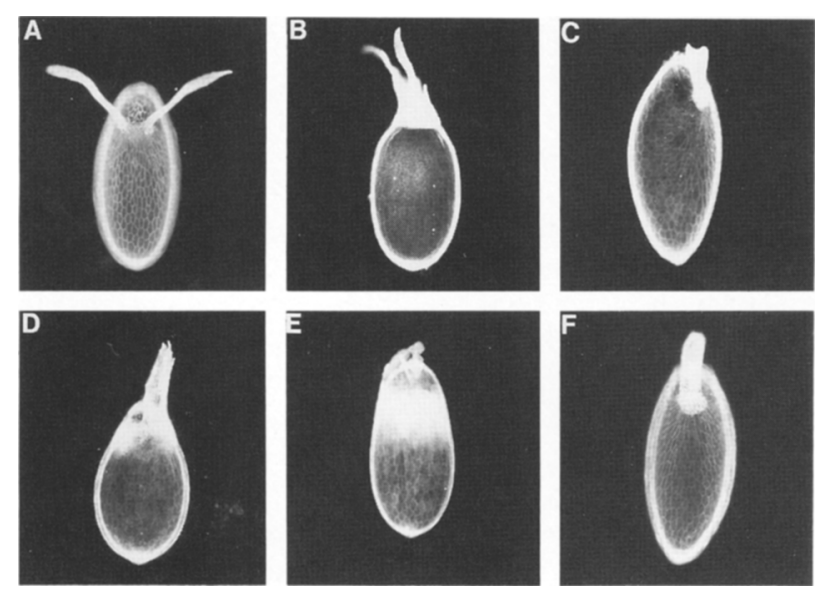

Figure 1. The eggshell is dorsalized when Raf is constitutively activated and ventralized when Raf activity is reduced. A constitutively active form of either the Drosophila or the human Raf kinase was expressed in females from a heat shock promoter (see Materials and methods). After 3 days of heat shocks, shifting to $37^{\circ} \mathrm{C}$ for $20 \mathrm{~min}$ twice a day, the females lay eggs that are clearly dorsalized, resembling eggs laid by females homozygous for the mutation $f s(1) K 10$ (cf. $D$ and $E$ with $B$ ): The dorsal appendages extend around the entire anterior circumference of the egg, which is shorter and rounder than wild type $(A)$. Conversely, eggs laid by females that express less active Draf $\left(D r a f^{H M 7} / D r a f^{H M 7}{ }_{;} F\right)$ are ventralized and are comparable with those laid by females mutant for the Drosophila EGF receptor

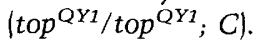

Table 1. Follicle cell imprints

\begin{tabular}{|c|c|c|}
\hline \multicolumn{2}{|c|}{ Genotype and chorion phenotype } & $\begin{array}{l}\text { Number of imprints } \\
\text { in lateral sector } \\
(\%)\end{array}$ \\
\hline$y w$ & wild type & $175(100)$ \\
\hline Draf ${ }^{H M 7}$ & ventralized & $204\langle 117\rangle$ \\
\hline$h s p 70-D r a f^{g o f} / T_{M} 3^{a}$ & dorsalized & $155 \mid 89)$ \\
\hline hsp $70-D r a f^{s o f} / T_{M} 3^{a}$ & more severe & $127(73)$ \\
\hline
\end{tabular}

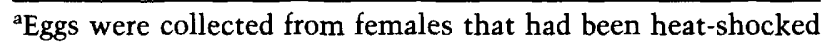
once daily for 3 days.

\section{Results}

Reducing Raf activity leads to ventralized eggs

We investigated whether Raf acts in signal transduction during oogenesis, in particular in the EGF signaling pathway. In Drosophila, Raf has been shown to act downstream of at least two RTKs, torso and sevenless (Ambrosio et al. 1989b; Dickson et al. 1992), but as yet not the EGF RTK. If Raf is required in dorsoventral signaling, then lowering the level of expression of Raf, or its activity, should lead to ventralized eggs resembling those produced by EGF receptor mutant females.

To obtain adult females with which to investigate possible oogenesis defects, we used a hypomorphic Draf mutation (Draf ${ }^{H M 7}$; see Materials and methods) (Kramers et al. 1983; Melnick et al. 1993). Whereas many Draf mutations behave as nulls and result in larval-pupal lethality, $\mathrm{Draf}{ }^{H M 7}$ mutants survive to adulthood and are fertile (Melnick et al. 1993; Perrimon et al. 1985). Draf ${ }^{H M 7}$ mutants exhibit a rough eye phenotype consistent with the role of Draf in the sevenless RTK signaling pathway (Dickson et al. 1992; Melnick et al. 1993).

The eggs laid by homozygous Draf ${ }^{H M 7}$ females (Fig. $1 F$ ) resemble strongly those laid by females homozygous for the EGF receptor mutation top ${ }^{1}$ (Schupbach 1987; Clifford and Schupbach 1989), as shown in Figure 1C. The eggshells are ventralized, with fused and shortened dorsal appendages, and the eggs are longer than wild type. The chorions of ventralized eggs show an increased number of follicle cell imprints, with more follicle cells giving rise to the main body of the chorion at the expense of the dorsal appendages (Schupbach 1987). The number of follicle cell imprints on eggs from Draf ${ }^{H M 7}$ mothers is $\sim 15 \%$ higher than wild type (Table 1). Dorsoventral polarity can, therefore, be disrupted by mutations that affect either the activity or the levels of the EGF RTK or Draf, implying that these two kinases participate in a common pathway.

\section{Expression of constitutively activated Raf during oogenesis dorsalizes the eggshell}

Constitutive activation of the dorsoventral signaling pathway during oogenesis should lead to a dorsalized egg phenotype, the converse phenotype to that observed when signaling is reduced by mutations in the EGF RTK, 
or in Draf. If Draf activity is sufficient for signaling, then ectopic expression of an activated form of the kinase should generate a dorsalized phenotype. Raf can be activated by deleting the amino terminus of the kinase, which is thought to encode a negative regulatory region (Stanton et al. 1989; Wasylyk et al. 1989; Bruder et al. 1992; Heidecker et al. 1992). Therefore, we expressed a constitutively activated form of either Drosophila or human Raf kinase in adult females and looked for an effect on oogenesis and embryonic development.

To create a heat-inducible, gain-of-function Raf gene $\left(R a f^{g o f}\right)$, we subcloned the coding sequence for aminoterminally deleted Drosophila (A. Brand, X. Lu, and N. Perrimon, in prep.) or human Raf (Heidecker et al. 1992) downstream of the $h s p 70$ promoter. Raf ${ }^{\text {gof }}$ was expressed by heat shocking females carrying the $h s p 70-$ Raf fof $^{\text {gene }}$ (see Materials and methods). After 3 days, in which heat shocks are administered once daily, the females lay eggs that are dorsalized and look similar to those laid by homozygous $f_{s}(1) K 10$ females (Fig. 1, cf. B with D). The dorsal appendages fuse in a ring at the anterior end, and the eggs are smaller and more spherical than wild type. A number of eggs exhibit a seemingly more severe phenotype where the dorsal appendages are reduced in size, or completely absent, and the chorion is deposited in a wide opaque band toward the anterior of the egg (Fig. 1E). The number of more severely affected eggs increases with the frequency and duration of the heat shock.

Higher levels of Raf, or increased kinase activity, may be responsible for the stronger chorion phenotype. This is supported by the result that expression of amino-terminally truncated human Raf, which appears to be more active than truncated Draf (A. Brand, X. Lu, and N. Perrimon, in prep.|, gives rise to more eggs displaying the stronger phenotype. Expression of Draf ${ }^{\text {gof }}$ causes $63 \%$ of the eggs to become $f s(1) K 10$-like, whereas $29 \%$ look more severe. By comparison, expression of human Raf ${ }^{\text {gof }}$ results in 55\% resembling $f_{s}(1)$ K10-like eggs and $43 \%$ showing the more severe phenotype (Table 2). Females homozygous for the hsp 70 -human Raf gof gene lay very few eggs after the third day of heat shock, of which twothirds are severely dorsalized (Table 2). Ectopic activation of Raf may also affect an earlier stage of oogenesis, during which Raf plays an as yet unidentified role.

In contrast to ventralized chorions, dorsalized egg- shells bear fewer follicle cell imprints. Counting the follicle cell imprints on eggs laid by hsp70-Drafgof females indicates $10 \%$ fewer imprints on the dorsalized chorions, and $25 \%$ fewer on the more severely affected eggs (see Table 1). Because the ectopic activation of either Draf or human Raf dorsalizes the egg, activating Raf appears to be sufficent to initiate dorsoventral signaling.

\section{Targeted expression demonstrates that Raf acts in the follicle cells to determine dorsoventral polarity}

Expression of $\mathrm{Raf}^{\text {gof }}$ from a heat shock promoter cannot resolve whether Raf acts in the oocyte or in the follicle cells, as the kinase may be expressed both in the germ line and in the soma. To ask in which tissue Raf ${ }^{\text {gof }}$ has its effect, we targeted expression of activated Raf to the follicle cells using the GAL4 system (Brand and Perrimon 19931, which permits ectopic expression to be directed to particular cells or tissues. An enhancerless GAL4 gene is integrated randomly in the genome, generating independent insertion lines in which GAL4 expression is directed by different genomic enhancers. It is then possible to introduce a gene containing GAL4-binding sites within its promoter, to activate the gene in those cells where GAL4 is expressed, and to observe the effect of this directed misexpression on development.

To create a GAL4-responsive Raf ${ }^{\text {gof gene (UAS-Raf }}{ }^{g o f}$ ), the human or Drosophila Raf ${ }^{\text {gof }}$ coding sequences were subcloned behind a tandem array of five optimized GAL4-binding sites (or UAS, for upstream activation sequence; see Materials and methods; Brand and Perrimon 1993). The UAS-Raf ${ }^{\text {gof }}$ gene is silent in the absence of GAL4. When GAL4 is introduced in a cross, GAL4 binds to the UAS and activates transcription.

We generated a library of $\sim 250$ independent GAL4 insertion lines (Brand and Perrimon 1993) and characterized the GAL4 expression patterns by crossing them to a line carrying a UAS-lacZ gene and staining their progeny for $\beta$-galactosidase activity (Brand and Perrimon 1993; D. McKearin, pers. comm.). We also crossed the lines to a line carrying $U A S-R a f^{\text {gof }}$, and screened for Rafdependent phenotypes.

One GAL4 insertion line, 55B, activates $U A S-1 a c Z$ in a stripe of follicle cells around the anterior of the oocyte in a stage 9 egg chamber (Fig. 2A). Embryonic GAL4 ex-

Table 2. Chorion phenotypes

\begin{tabular}{|c|c|c|c|c|}
\hline Genotype & Total & $\begin{array}{c}\text { Wild type } \\
|\%|\end{array}$ & $\begin{array}{c}\text { Dorsalized } \\
\qquad \% \mid\end{array}$ & $\begin{array}{c}\text { More severe } \\
(\%)\end{array}$ \\
\hline$y w$ & 100 & $100(100)$ & 0 & 0 \\
\hline hsp70-Drafgof $/$ TM3 $^{\mathrm{a}}$ & 99 & $8(8)$ & $62(63)$ & $29(29)$ \\
\hline hsp 70 -human rafsof $/ T M 3^{\mathrm{a}}$ & 65 & $1(2)$ & $36\langle 55\rangle$ & $28(43)$ \\
\hline hsp $70-$ human rafgofa & 9 & $1(11)$ & $2(22)$ & $6(67)$ \\
\hline$U A S-D r a f^{g o f} / p G a w B^{55 B b}$ & 213 & $94(44)$ & $119(56)$ & 0 \\
\hline$U A S-$ human Rafsof $;$ pGawB $B^{55 \mathrm{Bb}}$ & 144 & $5(3)$ & $139(97)$ & 0 \\
\hline
\end{tabular}

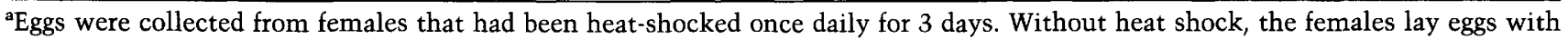
wild- type chorions.

'In the absence of GAL4, UAS-Drafgof and UAS-human Rafof females lay eggs with wild-type chorions. 


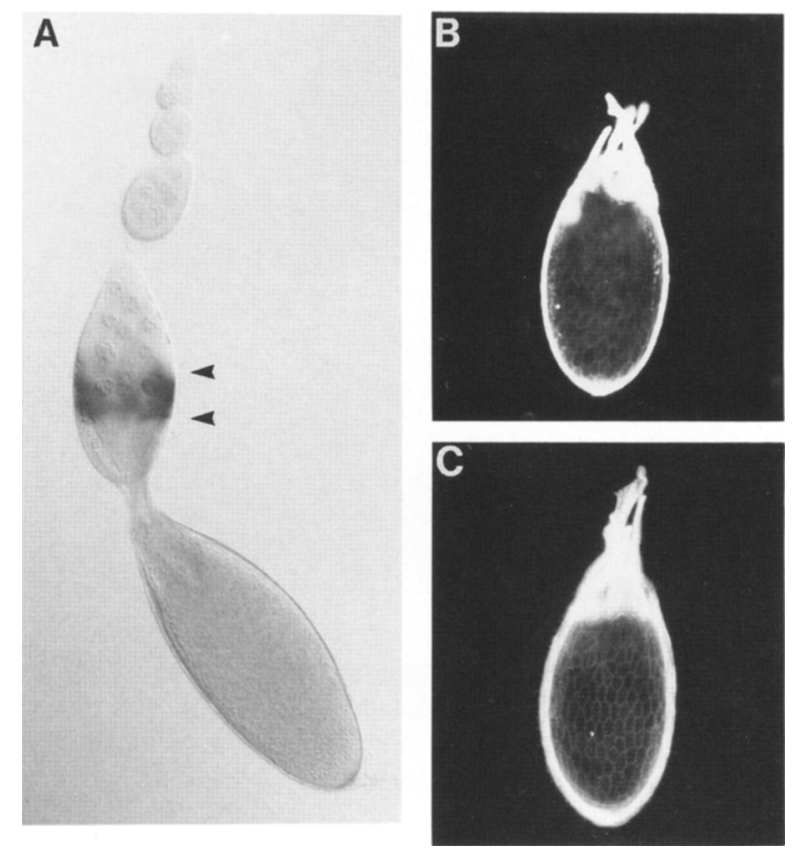

Figure 2. Targeted expression demonstrates that Raf acts in the follicle cells to determine the dorsoventral polarity of the egg. The dorsoventral polarity of the egg is established by signaling between the oocyte and the somatic follicle cells. As such, the polarity of the eggshell can be disrupted by mutations that affect either the germ line (such as $f s(1) K 10$ ) or the follicle cells (such as $D E R$ ). Using the GAL4 system to target gene expression (Brand and Perrimon 1993), we show that expression of activated Raf within the follicle cells leads to a dorsalized phenotype. The enhancer trap/GAL4 insertion 55B expresses GAL4 in the follicle cells of a stage 9 egg chamber, as shown in $A$ where GAL4 insertion 55B drives expression of a $U A S-1 a c Z$ gene $\left(\beta g^{4-1-2}\right)$. X-gal staining shows cytoplasmic $\beta$-galactosidase expression in a band of follicle cells surrounding the anterior end of the oocyte (marked by arrowheads). When line GAL4 insertion $55 B$ is used to activate UAS-Drafof or UAS-human $R a f$ fof in the anterior follicle cells, the resultant eggs are dorsalized $(B$ and $C$, respectively).

pression is restricted to the salivary glands. When line $55 \mathrm{~B}$ is crossed to flies carrying UAS-Drafgof or UAShuman Rafgof, to express Rafoof specifically within the anterior follicle cells, the female progeny lay dorsalized eggs as judged by their chorion phenotypes (Fig. 2B,C; Table 2). Activating Raf in the follicle cells is, therefore, sufficient to dorsalize the egg, suggesting that Raf is required in the follicle cells, rather than in the oocyte, to specify dorsoventral polarity.

\section{Activated Raf induces ventral follicle cells to assume a dorsal cell fate}

Expressing Rafgof in follicle cells might direct a cell fate switch, such that the ventral and lateral follicle cells assume a dorsal fate. To assay whether activated Raf can induce a cell fate change, we monitored the expression of a marker that is normally restricted to the dorsal anterior follicle cells. We used the transgenic line AN296 (T. Schupbach, unpubl.), which carries an enhancer trap lacZ gene. The lacZ gene has integrated near a genomic enhancer that directs expression specifically in the dorsal anterior follicle cells (Figs. 3A, 4A, and 5A).

We expressed activated Raf from the hsp70-Drafof gene in the AN296 background and assayed $\beta$-expression in ovaries. After three or four heat shocks, all the follicle cells over the oocyte in a stage 10 egg chamber express the previously restricted dorsal marker (Fig. 3B). At stage 12 or 13 , in a wild-type egg chamber, $\beta$-galactosidase expression is primarily restricted to the follicle cells that

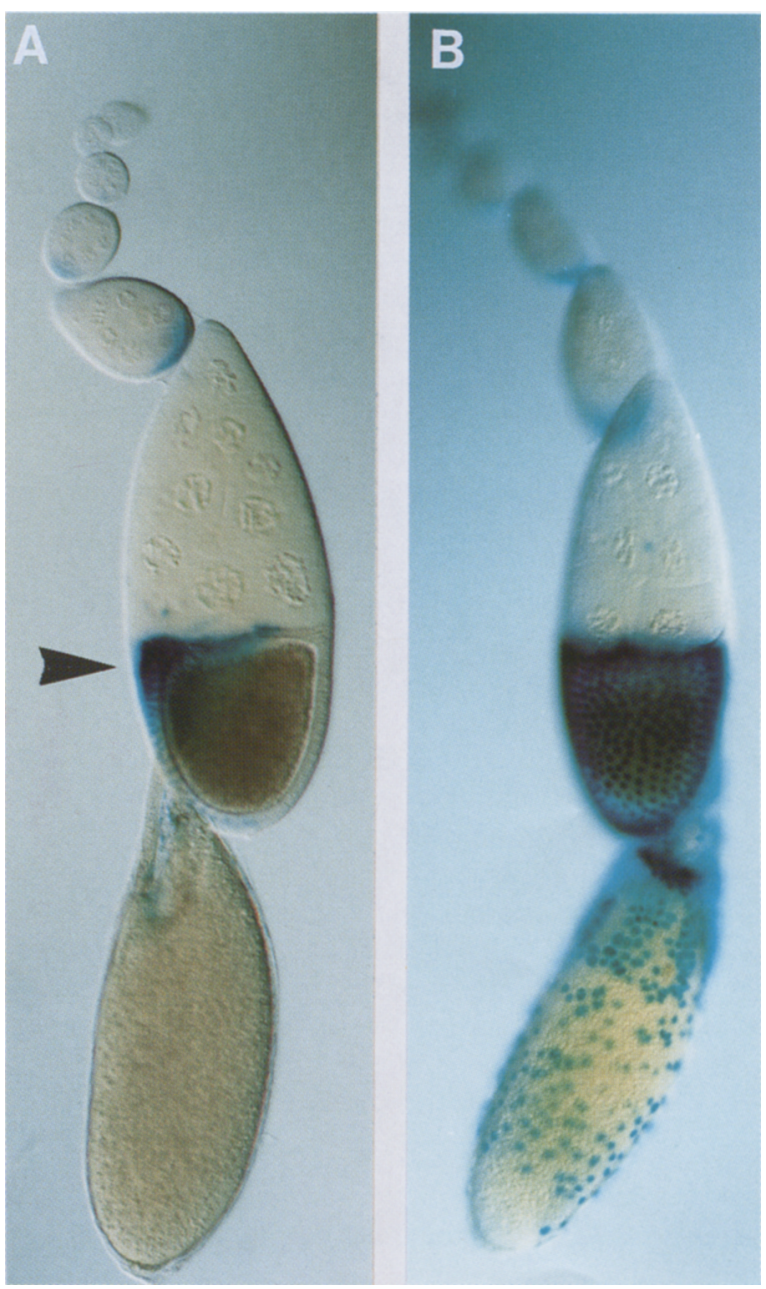

Figure 3. Activated Raf induces ventral follicle cells to adopt a dorsal cell fate. The dorsal anterior follicle cells can be marked by $\beta$-galactosidase expression from the enhancer trap/lac $Z$ insertion AN296 (T. Schupbach, pers. comm.), as demonstrated by $\mathrm{X}$-gal staining of an ovariole from a female carrying two copies of AN296. (A) In a stage 10 egg chamber only the follicle cells in the vicinity of the oocyte nucleus, which has migrated to a dorsoanterior position, stain. $(B)$ In females that express Drafgof from a heat shock promoter, $\beta$-galactosidase expression from AN296 can be detected in all of the follicle cells overlying the oocyte. 

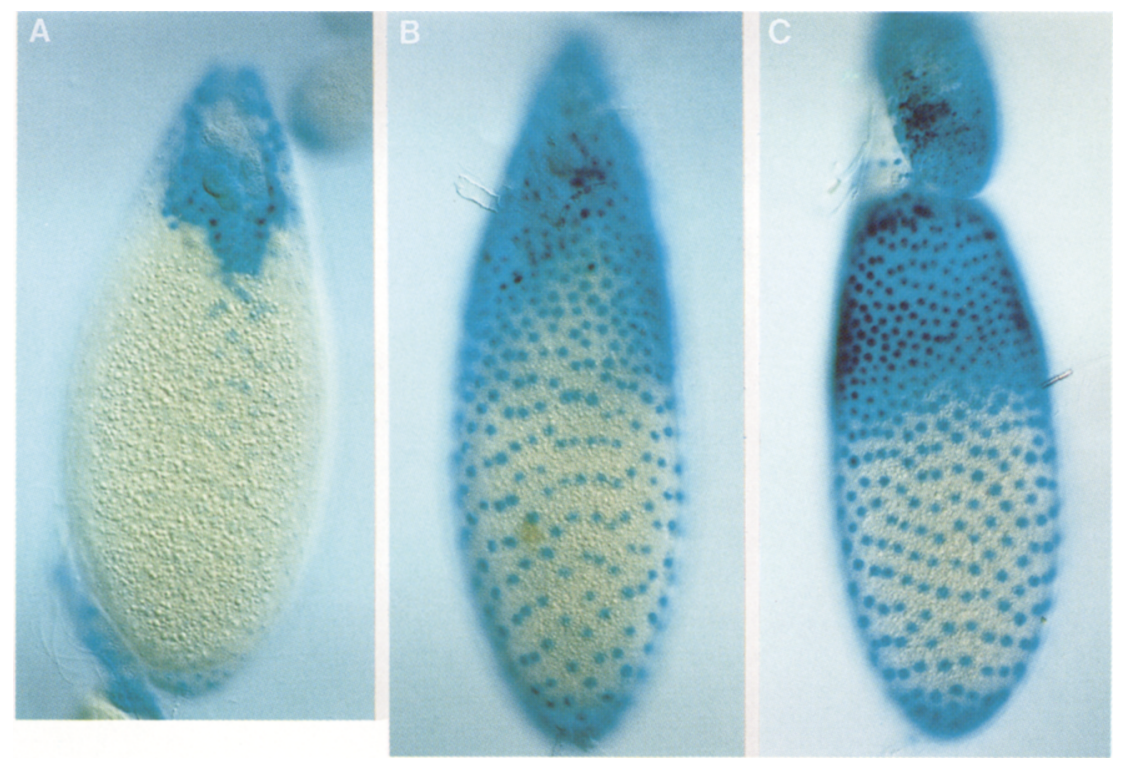

Figure 4. Constitutive activation of Raf alters the morphology of the egg chamber. Stage 12 and 13 egg chambers from females expressing lacZ insertion AN296. (A) In wild-type animals, transcription of AN296 is primarily limited to the follicle cells that will give rise to the dorsal appendages. $(B)$ In females expressing activated Drafgof from a heat shock promoter, all of the follicle cells express AN296. (C) In some cases, a ring of densely packed follicle cells can be seen around the anterior end of the oocyte. These egg chambers may give rise to the most severely dorsalized eggs (see Fig. 1E).

give rise to the dorsal appendages (Fig. 4A). Expression of activated Raf induces all follicle cells to express $\beta$-galactosidase (Fig. 4B) and can result in a ring of densely packed follicle cells around the entire anterior circumference of the oocyte (Fig. 4C). The size and shape of the

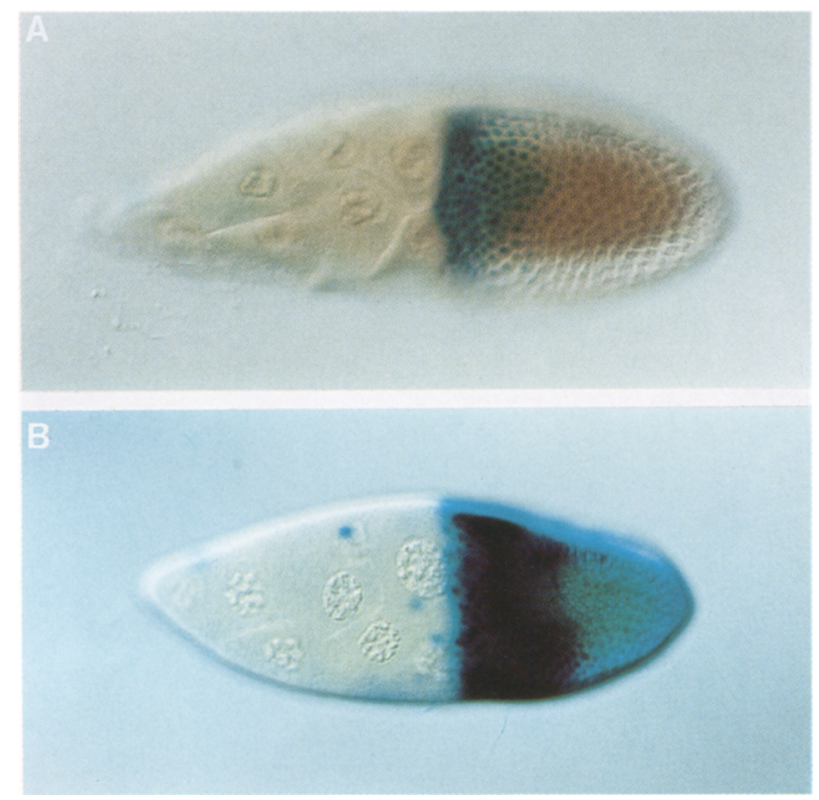

Figure 5. Targeted expression of Raf ${ }^{\text {gof }}$ dorsalizes the anterior follicle cells. Stage 10 egg chambers stained with X-gal to show: (A) $\beta$-Galactosidase expression from the enhancer trap/lac $Z$ insertion, AN296, in a wild-type ovary and $(B)$ targeted expression of activated human Raf, using the GAL4 insertion $55 B$, results in a high level of AN296 expression in a band of follicle cells surrounding the anterior end of the oocyte (cf. with Fig. 2A, showing the expression pattern of UAS-lacZ driven by GAL4 insertion $55 B \mid$. egg chambers that exhibit an increased clustering of follicle cells suggest that they may give rise to the more severely dorsalized eggs (see Fig. 1E).

When UAS-human Rafof expression is driven by GAL4 insertion 55B, expression of activated Raf is targeted primarily to the anterior dorsal and ventral follicle cells. In the AN296 background, the anterior dorsal and ventral follicle cells express $\beta$-galactosidase most highly (Fig. 5B). The remaining follicle cells over the oocyte express lower levels of $\beta$-galactosidase. Expression of activated Raf, either from hsp 70-Drafsof or by GAL4 activation of UAS-human Raf fof, in ventral follicle cells is sufficient to transform ventral cells toward a dorsal cell fate.

\section{Expression of activated Raf dorsalizes the embryo as well as the chorion}

We have shown that the ectopic activation of Raf is sufficient to dorsalize the chorion. Raf might act only to specify the fate of the dorsal follicle cells or, alternatively, localized kinase activation might also contribute to the dorsoventral polarity of the developing embryo. Therefore, we asked whether ectopic activation of Raf dorsalizes the developing embryo.

We prepared cuticles from embryos derived from females expressing Raf ${ }^{\text {gof }}$ during oogenesis. Most of the eggs laid by females expressing activated Raf cannot be fertilized because of their dorsalized chorions (Tables 2 and 3 . . Of the fertilized eggs from females expressing UAS-human Raf fof , 25\% give rise to dorsalized embryos (Fig. 6B). In the most severe cases, the embryos are twisted and lack nearly all ventral structures, such as the thoracic and abdominal denticle belts seen in a wild-type larva (Fig. 6A). More dorsally derived structures, such as the filzkorper, are still present (Fig. 6B). Embryos from hsp70-Draffof females are comparably dorsalized. Fe- 
Table 3. Cuticle phenotypes

\begin{tabular}{|c|c|c|c|c|c|}
\hline Genotype & $\Sigma$ & $\begin{array}{c}\text { Fertilized } \\
(\%)\end{array}$ & $\begin{array}{c}\text { Wild type } \\
(\%)\end{array}$ & $\begin{array}{c}\text { Dorsalized } \\
(\%)\end{array}$ & $\begin{array}{r}\text { Weak }^{\mathrm{a}} \\
|\%|\end{array}$ \\
\hline$U A S-D r a f^{g \circ f} / p G a w B^{55 B}$ & 150 & $126(84)$ & $101 / 126(80)$ & $4 / 126(3)$ & $21 / 126(17)$ \\
\hline UAS-human $\operatorname{Raf}^{g \circ{ }^{\prime}} ;$ pGaw $B^{55 B}$ & 117 & $28(24)$ & $11 / 28(39)$ & $7 / 28(25)$ & $10 / 28(36)$ \\
\hline
\end{tabular}

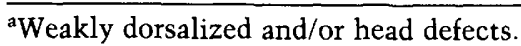

males expressing UAS-Draf ${ }^{\text {gof }}$ produce far fewer dorsalized embryos $(3 \%)$, suggesting that higher levels or activity of Raf are required to dorsalize the embryo as opposed to the chorion.

\section{Raf acts downstream of the EGF receptor}

We have shown that Raf acts in the follicle cells to relay a signal that establishes the dorsoventral polarity of the eggshell and the embryo. The phenotypes seen when Raf is ectopically activated, or when Raf activity is reduced,
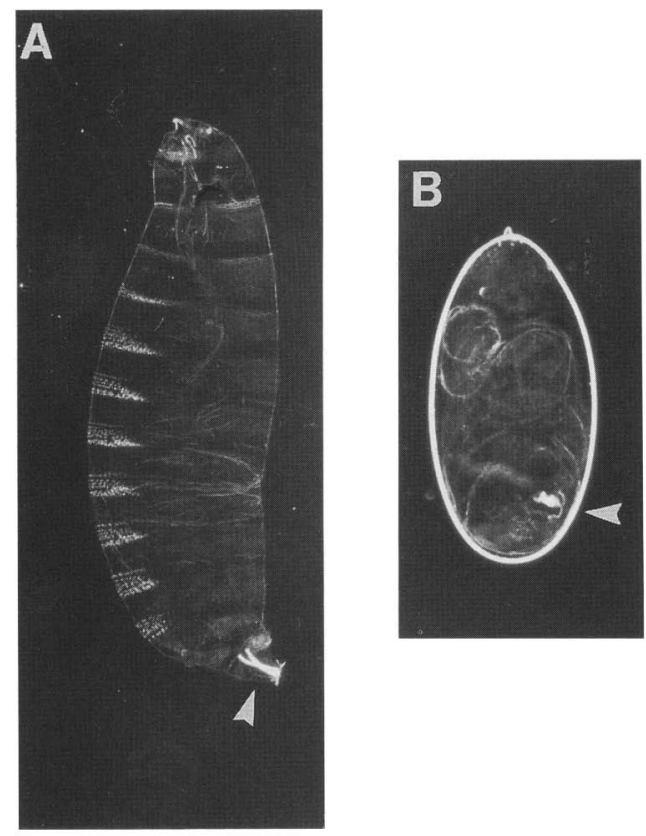

Figure 6. Activated Raf dorsalizes the embryo as well as the eggshell. Mutations that affect the dorsoventral pattern of the chorion can also alter the polarity of the embryo developing within the eggshell. When activated Raf is ectopically expressed, most eggs are dorsalized and as a result cannot be fertilized (76\%, UAS-human Rafsof). In those eggs that are fertilized, however, $61 \%$ of the embryos are dorsalized. (A) A cuticle prepared from a wild-type larva (the vitelline membrane has been removed), showing the denticle bands on the ventral surface of the animal; $(B)$ a cuticle prepared from an embryo laid by a female expressing UAS-human Rafof as directed by GAL4 insertion 55B. The embryo is twisted and lacks the ventral denticle bands, whereas the dorsally derived filzkörper is still present (arrowhead). In many embryos the dorsalization is more pronounced at the anterior end, as has been reported for $f_{S}(1) K 10$ (Wieschaus 1979). suggest that Raf might act downstream of the Drosophila EGF receptor. We examined the relationship between Raf and $D E R$ by expressing Raf ${ }^{\text {gof }}$ in a $D E R$ mutant background. If Raf acts downstream of $D E R$, then activating Raf will overcome the need for a functional EGF RTK. The resultant eggs should therefore be dorsalized. If Raf acts upstream of $D E R$, the absence of $D E R$ will suppress the dorsalized phenotype, and the eggs will be ventralized. If the two genes function in separate pathways, an intermediate phenotype might be obtained.

Using the GAL4 system, flies that are homozygous for the DER mutation, top ${ }^{1}$, can be made to express activated human or fly Raf in their follicle cells. Whereas top ${ }^{1}$ females normally lay ventralized eggs (Fig. 7A), in the presence of constitutively active Draf (Fig. 7B) or human Raf (Fig. 7C) their egg shells are dorsalized. Similarly, expression of UAS-human $R a f^{g o f}$ in $t^{1} p^{1} /$ top $^{\mathrm{CJ}}$
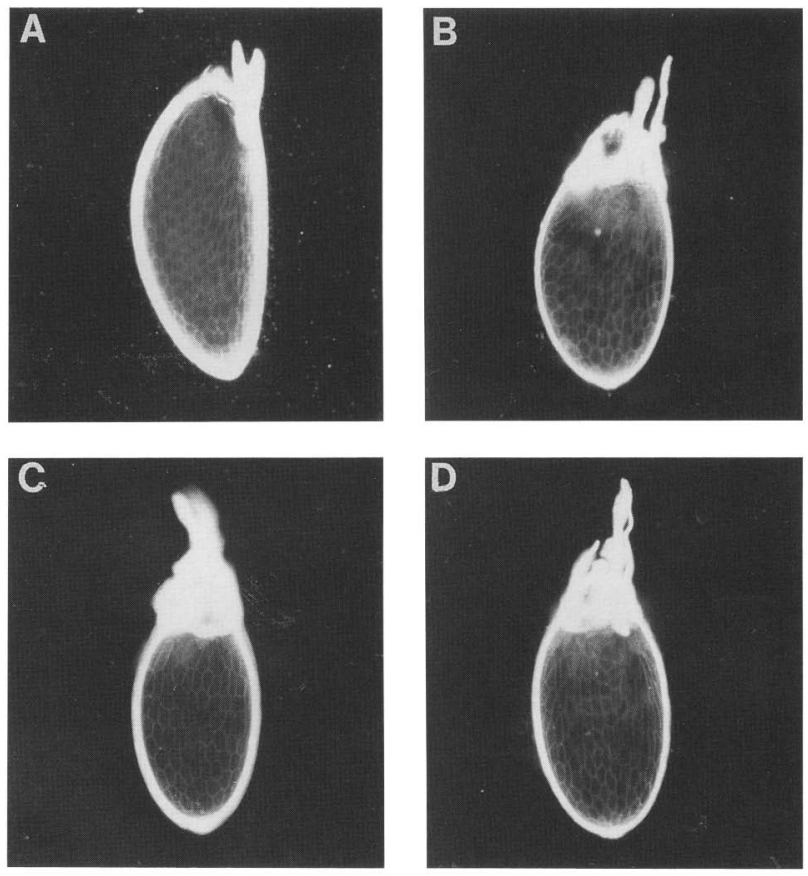

Figure 7. Raf acts downstream of the EGF receptor. Females that are homozygous for mutations in the Drosophila EGF receptor (such as top ${ }^{Q Y 1} /$ top $^{Q Y 1}$ ) lay eggs that are ventralized, as shown in $A$. When $\mathrm{Raf}^{\text {gof }}$ is expressed in these females they lay dorsalized eggs, demonstrating that Rafgof is epistatic to DER. Expression of either Drafgof $\langle B\rangle$ or human Raf ${ }^{\text {gof }}(C, D)$ in the anterior follicle cells of females mutant for $D E R\left(B, C: t_{0} p^{\mathrm{QY} 1} /\right.$ top ${ }^{Q Y 1}$; $D:$ top $\left.^{\mathrm{QY1} / \text { top }} \mathrm{p}^{\mathrm{C}}\right)$ dorsalizes the egg chamber. 
females results in dorsalization (Fig. 7D). Because expression of UAS-Drafgof or UAS-human Rafsof in the anterior dorsal and ventral follicle cells is sufficient to dorsalize eggs from $D E R$ mutant mothers, our results strongly suggest that Raf acts downstream of $D E R$.

\section{Discussion}

Raf is a cytoplasmic serine/threonine that can transduce signals from several different receptor tyrosine kinases. In mammalian cells, Raf acts downstream of the platelet-derived growth factor and EGF RTKs (Morrison et al. 1988). During vulval induction in Caenorhabditis elegans a Raf homolog encoded by the lin- 45 gene is required for signaling by the EGF RTK and Ras, encoded by let-23 and let-60, respectively (Aroian et al. 1990; Beitel et al. 1990; Han and Sternberg 1990; Han et al. 1993). In Drosophila, Raf has been shown to relay signals from the torso RTK to determine the fates of the embryonic ter- mini (Ambrosio et al. 1989b), and from the sevenless RTK to specify the fate of the R7 photoreceptor cell (Dickson et al. 1992). Here we demonstrate a novel role for Raf in Drosophila development, in specifying the dorsoventral polarity of the egg chamber. We show that Raf functions in the somatic follicle cells to transduce a signal from the Drosophila EGF receptor (Fig. 8).

When Raf activity or expression levels are lowered by means of the hypomorphic mutation Draf ${ }^{H M 7}$, females lay ventralized eggs. The eggs are longer than wild type, have fused and shortened dorsal appendages, and exhibit more follicle cell imprints. The phenotype is presumably attributable to reduced signaling through the EGF receptor pathway. When constitutively active Raf kinase is expressed during oogenesis, the dorsoventral signal transduction pathway is ectopically activated, resulting in dorsalized eggs and embryos. Expression of activated Raf is sufficient to dorsalize both the chorion and the embryo, whereas the Draf ${ }^{H M 7}$ mutation only ventralizes the chorion. The chorion may be a more sensitive indi-

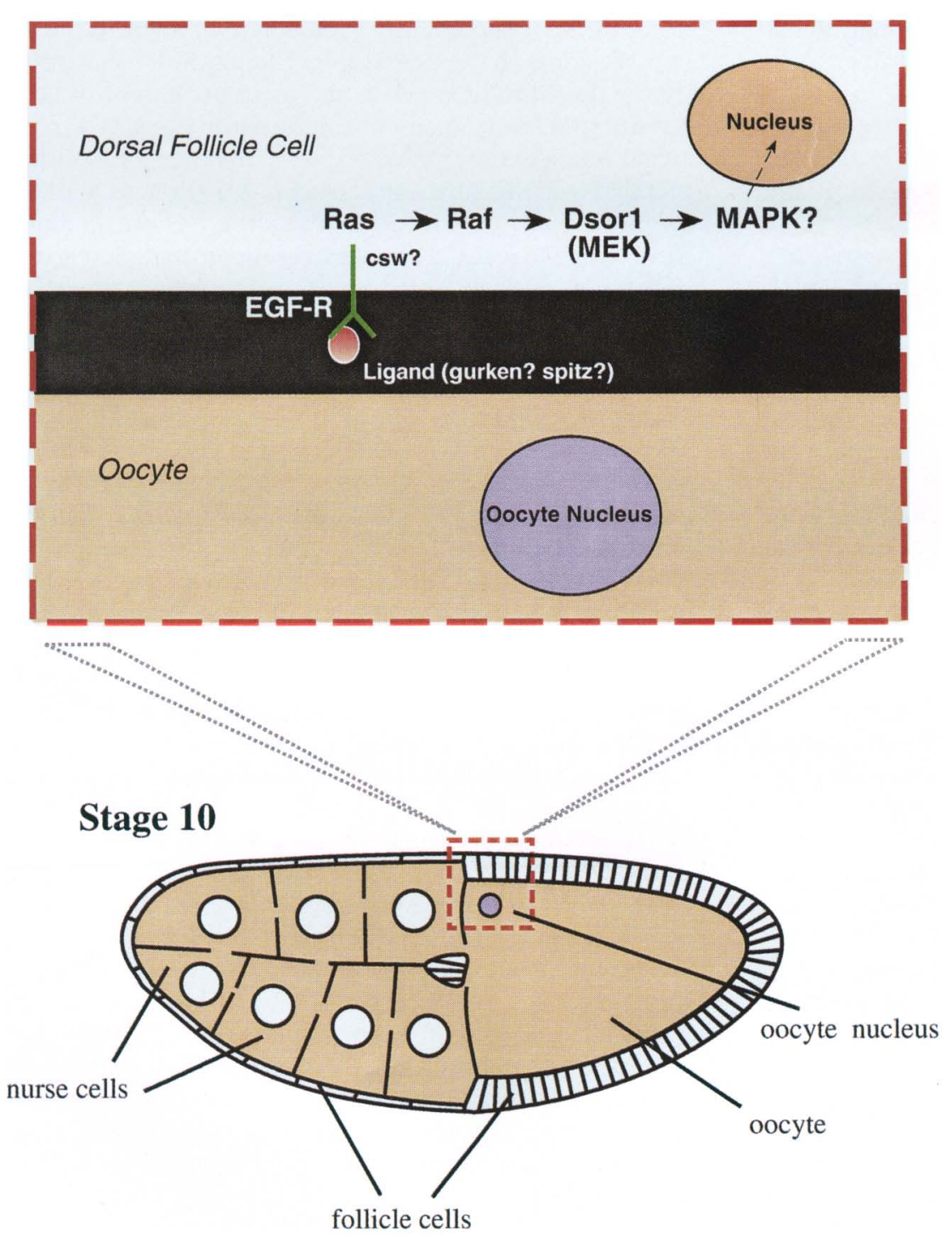

Figure 8. Raf transmits a signal from the EGF receptor to specify the dorsoventral polarity of the egg chamber. A diagrammatic representation of a stage $10 \mathrm{egg}$ chamber. The region within the red box has been enlarged to show a segment of the dorsal side of the egg chamber. By this stage of development, the oocyte nucleus has migrated to the prospective dorsal side of the oocyte. The oocyte sends a signal to the dorsal follicle cells. This signal may be in the form of a ligand for the EGF receptor. Potential candidates for a ligand for $D E R$ include gurken and spitz. Activation of the EGF receptor initiates a signal transduction cascade that (1) determines the fate of the dorsal follicle cells and (2) establishes the polarity of the developing embryo. Draf seems to act downstream of the EGF receptor in both of these processes. In addition to Raf, several other signaling molecules have been shown to act downstream of the torso and sevenless RTKs. These include csw, Ras, and the MAP kinase activator (or MEK) encoded by Dsor 1 . Recent evidence suggests that these molecules also participate in dorsoventral signaling (L. Perkins, X. Lu, I. Duffy, and N. Perrimon, unpubl.). 
cator of Raf activity than the embryo, such that ventralized embryos would only be seen after Raf levels were further reduced.

Raf can be activated by amino-terminal deletions that are thought to remove a negative regulatory domain. This model has been supported recently by work showing that the amino terminus of Raf interacts directly with Ras (Vojtek et al. 1993; Warne et al. 1993; Zhang et al. 1993|. Ras may activate Raf by binding to the aminoterminal negative regulatory domain and releasing the carboxy-terminal kinase domain from negative regulation. A single amino acid substitution within the amino terminus of Draf, isolated as the hypomorphic mutation C110, may thus interfere with the Ras-Raf interaction and result in a less active kinase (Melnick et al. 1993; Voitek et al. 1993). Expression of an amino-terminal region of Raf leads to a dominant negative phenotype in mammalian tissue culture cells (Bruder et al. 1992), suggesting that the amino terminus can compete with wildtype Raf for interaction with Ras.

When constitutively activated Raf is expressed throughout the egg chamber, the eggshell and the developing embryo are dorsalized. Therefore, although Raf is normally transcribed throughout the egg chamber (Ambrosio et al. 1989b), Raf activation appears to be restricted. To show that Raf acts in the somatic follicle cells rather than in the germ line, we targeted expression of Raf ${ }^{\text {gof }}$ to follicle cells using the GAL4 system (Brand and Perrimon 1993). The GAL4 system allows ectopic expression to be directed to particular cells or tissues. Expressing Raf ${ }^{\text {gof }}$ within the follicle cells alone dorsalizes the egg chamber. These results suggest that Raf is normally activated only within the dorsal follicle cells, and that activation within the ventral cells is sufficient to dorsalize the egg. We used GAL4 insertion line 55B to target expression of Rafgof primarily to an anterior band of follicle cells. The levels of activation directed by GAL4 in this line appears to be somewhat variable from cell to cell, as judged by GAL4-mediated $\beta$-galactosidase expression. In spite of this, consistently we observe dorsalized eggs from expression of Rafgof (Table 2), suggesting that the follicle cells are sensitive to small changes in the levels of Raf activity.

The dorsal signal emanating from the oocyte may form a gradient, and thus activate the EGF RTK pathway to different degrees depending on the concentration of ligand. This would be similar in principle to the the terminal class signal transduction pathway, where a ligand concentrated at the termini appears to result in a gradient of activation through the torso RTK (Casanova and Struhl 1989; Perkins et al. 1992; Melnick et al. 1993). High levels of torso activity lead to transcription of the genes tailless and huckebein, whereas lower levels of activity only support tailless transcription.

We were able to follow Rafgof-induced cell fate changes by monitoring the expression of a dorsal follicle cell marker, the enhancer trap/lacZ insertion AN296. AN296 normally is expressed in a gradient radiating from the dorsal follicle cells. AN296 is expressed in all follicle cells in response to expression of $h s p 70-R a f^{\text {gof }}$, and is transcribed strongly in a band of anterior follicle cells in response to targeted expression of UAS-Rafgof.

To test whether Raf acts downstream of the EGF receptor, we expressed activated Raf in the dorsal and ventral follicle cells of $D E R$ mutant females. In the absence of activated Raf, $D E R$ mutants lay ventralized eggs. When activated Raf is expressed in their follicle cells, however, they lay dorsalized eggs. Because activating Raf overcomes the requirement for $D E R$ in specifying the dorsal follicle cell fate, Raf appears to act downstream of the EGF receptor. We have not ruled out the possibility that artificially activated Raf acts as a promiscuous kinase, and in this way bypasses the requirement for EGF receptor activation. However, the fact that loss-of-function and gain-of-function Raf mutants have opposite effects on dorsoventral signaling strongly suggests that Raf normally functions in the $D E R$ signal transduction pathway.

The Ras interaction domain within the amino terminus of Raf appears to be conserved between mammals, Drosophila and C. elegans (Han et al. 1993; Melnick et al. 1993; Vojtek et al. 1993) suggesting that Ras and Raf from different species might associate in a similar fashion. We show that expression of human Rafgof can specify the dorsal follicle cell fate. Given the extent of conservation between many of the receptor tyrosine kinase signal transduction pathways, it seems likely that other members of the torso and sevenless pathways will be implicated in dorsoventral signaling. These include Ras1, Gap1 (a Ras GTPase-activating protein) and Sos (a guanine nucleotide exchange factor) acting upstream of Raf, csw (a tyrosine phosphatase) acting upstream of Raf or in a parallel pathway, and MEK and MAP kinase (Biggs and Zipursky 1992; Tsuda et al. 1993) acting downstream of Raf (Fig. 8). This is supported by recent results that suggest that Ras1, Gap1, csw, and Dsor1 (the Drosophila MEK homolog/ act in the dorsoventral pathway (Chou et al. 1993; X. Lu, L. Perkins, J. Duffy, and N. Perrimon, unpubl.).

Of the maternal effect genes that affect the dorsoventral polarity of both the egg and the developing embryo, only $D E R$, rhomboid, and Draf are required in the follicle cells. The factors downstream of $D E R$, such as wind beutel, nudel, and pipe, affect only the embryonic dorsoventral axis, and are thought to generate the ligand for the receptor Toll, which specifies the ventral side of the embryo (Anderson et al. 1985; Hashimoto et al. 1988, 1991; Stein et al. 1991; Stein and Nüsslein-Volhard 1992). DER is proposed to have at least two roles during oogenesis: (1) to determine the dorsal follicle cell fate, and (2) to block the production of the ligand dorsally. Screening for enhancers and suppressors of the dorsalized phenotype produced by Raf ${ }^{\text {gof }}$ will be one means of identifying novel factors downstream of $D E R$, those that affect the egg and the embryo, and those that affect only the embryo. It may then be possible to distinguish factors common to each of these processes, as well as to identify possible branch points in the two pathways. One target of $D E R$ and Raf appears to be the $1 a c Z$ fusion gene in line AN296, which is transcribed in response to Raf 
activation. The gene identified by this enhancer trap insertion might be involved in the morphological changes induced in the dorsal follicle cells, or could encode a negative regulator of windbeutel, nudel, and pipe.

\section{Materials and methods}

\section{Drosophila strains}

Flies were raised on standard Drosophila media at $25^{\circ} \mathrm{C}$, unless otherwise noted. Descriptions of balancers and mutations that are not described in the text can be found in Lindsley and Zimm (1992).

The Draf allele used in this study is Draf ${ }^{H M^{7}}$ (Kramers et al. 1983; Melnick et al. 1993). Draf ${ }^{H M 7}$ fails to complement the Draf deficiency $D f(1) 64 C 18$, and can be rescued by a P-transposable element carrying the Draf gene contained within a 4.3kb genomic BamHI fragment (Nishida et al. 1988). The Draf ${ }^{H M 7}$ gene has been cloned and sequenced, but no amino acid change has been found within the coding region, suggesting that the mutation may reside within transcriptional regulatory sequences and result in reduced levels of Draf expression (Melnick et al. 1993).

The EGFR mutations, top ${ }^{1}$ and top ${ }^{C I}$, were kindly provided by T. Schupbach, and are described in detail by Schupbach (1987) and Clifford and Schupbach (1989). $f s(1) K 10^{1}$ was kindly provided by $\mathrm{E}$. Wieschaus and has been previously described (Wieschaus et al. 19781.

The enhancer trap/lacZ line, AN296 (T. Schupbach, unpubl.), carries the P-transposable element described by Bier et al. (1989) and was a kind gift from T. Schupbach.

\section{Gene fusions}

A cDNA encoding the human Raf kinsase, deleted between amino acids 2 and 334, (Heidecker et al. 1992) was excised as a $B a m H I$ to $X b a I$ fragment from plasmid pRafBB la gift from N. Williams) and subcloned into the BglII and $X b a I$ sites of P-element vector pCaSpeR-hs (described by Thummel and Pirotta 1992) to make phs $\Delta$ c-Rafl.

The coding sequence for an amino-terminally truncated version of Draf was subcloned as an EcoRI to XbaI fragment from vector pUAS-Draf (A. Brand, X. Lu, and N. Perrimon, in prep.) into EcoRI and $\mathrm{XbaI}$ cut pCaSpeR-hs, to make phs $\Delta$ Draf. The Draf-coding sequence is deleted between amino acids 2 and 431, based on the amino acid sequence reported by Melnick et al. (1993).

To create a gene under the control of the yeast transcriptional activator GAL4, a cDNA encoding the truncated version of human Raf-1 ( $\Delta 2-334)$ was subcloned as an EcoRI-XbaI fragment into vector pUAST (Brand and Perrimon 1993) to give pUAS$\Delta \mathrm{cRaf}$. The construction of the UAS- $-\Delta$ Draf fusion gene will be described in detail elsewhere (A. Brand, X. Lu, and N. Perrimon, in prep.).

\section{P-element transformation}

Transgenic lines were generated by injection of $\mathrm{CsCl}$ banded DNA, at a concentration of $600 \mu \mathrm{g} / \mathrm{ml}$, into embryos of strain $y$ $w_{;}+/+$; Sb, P [ry +, $\left.\Delta 2-3\right] / T M 6, U b x$ (Robertson et al. 1988) using standard procedures (Spradling 1986). Several independent transformants were obtained for each construct. In this study we use lines $h s \Delta \mathrm{c}-R a f 1^{4-1-4} / T M 3$ or $h s \Delta \mathrm{c}-R a f 1^{4-1-4} / h s \Delta \mathrm{c}$ Raf $1^{4-1-4}$ to express hsp70-human Rafgof and hs $\Delta$ Draff $f^{F 2} / T M 3$ (A. Brand, X. Lu, and N. Perrimon, in prep.) to express hsp 70 Draf ${ }^{\text {gof }}$. For GAL4-mediated expression of UAS-human Raf ${ }^{\text {gof }}$, line UAS- $\Delta c R a f 1^{\text {ra2 }} / U A S-\Delta c R a f 1^{\text {ra2 }}$, in which UAS-human Raf ${ }^{\text {gof }}$ is carried on the X chromosome, is crossed to the GAL4 insertion line $p G a w B^{55 B}$ (see below). To express UAS-Drafof, we use line $U A S-\triangle D r a f^{F 179} / U A S-\triangle D r a F^{F 179}$, in which UASDraf ${ }^{\text {gof }}$ is inserted on the third chromosome (A. Brand, X. Lu, and N. Perrimon, in prep.).

\section{Heat shock regimen}

Females of the genotypes $h s \Delta c-R a f 1^{4-1-4} / T M 3$, hs $\Delta c-R a f 1^{4-1-4}$ / $h s \Delta c-R a f 1^{4-1-4}$ or $h s \Delta D r a f^{F 22} / T M 3$ were reared at room temperature, and then heat shocked in vials submerged in a $37^{\circ} \mathrm{C}$ water bath. Heat shocks were administered once or twice daily for 15-20 min, after which the flies were transferred immediately to fresh food at room temperature. Eggs were collected overnight and mounted in Hoyer's: lactic acid (1:1). After 3 days, $90 \%$ of the eggs exhibit dorsalized chorions (Table 2 ).

\section{The GAL4 system}

To express activated Raf in ovaries, we used a novel system for targeting gene expression (the GAL4 system; Brand and Perrimon 1993). An enhancerless gene encoding the yeast transcriptional activator GAL4 is inserted randomly into the Drosophila genome where, depending on the site of integration, expression is directed by any one of a diverse array of genomic enhancers. A second gene, containing GAL4-binding sites within its promoter, can then be introduced into this background where it will only be transcribed in those cells where GAL4 is expressed.

An enhancer detection screen was carried out to recover lines that express GAL4 in a cell- or tissue-specific manner (Brand and Perrimon 1993). Each of the 220 independent GAL4 insertion lines we recovered was crossed to a line carrying the UASlacZ reporter gene (UAS-lac $Z^{4-1-2}$; Brand and Perrimon 1993). Embryos from the cross were stained for $\beta$-galactosidase expression with anti- $\beta$-galactosidase antibodies. The lines were then crossed to line UAS- $\Delta c R a f 1^{\text {ra2 }}$ to screen for Raf ${ }^{\text {gof }}$-dependent adult phenotypes.

\section{$\mathrm{pGawB}^{55 \mathrm{~B}}$}

Females derived from a cross between GAL4 insertion line, $p G a w B^{55 B}$, and $U A S-\triangle c R a f 1^{r a 2}$ survive to adulthood and lay dorsalized eggs. $p G a w B^{55 B}$ carries an enhancer trap/GAL4 vector (pGawB; Brand and Perrimon 1993) inserted on the third chromosome.

To characterize the ovarian GAL4 expression pattern, GAL4directed expression of $\beta$-galactosidase was assayed. Line $p$ Gaw $B^{55 B}$ was crossed to line UAS-lacZ ${ }^{4-1-2}$ (Brand and Perrimon 1993), and the progeny of the cross were allowed to develop to adults. Females were fed for 3-5 days, and ovaries were then dissected and stained for $\beta$-galactosidase activity, as described below.

\section{Staining ovaries for expression of $\beta$-galactosidase}

Ovaries were dissected in PBS, $0.1 \%$ Triton X-100 and fixed in $1 \%$ glutaraldehyde for $15-20 \mathrm{~min}$. They were then washed in PBS, $0.1 \%$ triton $\mathrm{X}-100$ and stained in a solution of $10 \mathrm{~mm}$ $\mathrm{NaH}_{2} \mathrm{PO}_{4} / \mathrm{Na}_{2} \mathrm{HPO}_{4}$ (pH 7.2), $150 \mathrm{~mm} \mathrm{NaCl}, 1 \mathrm{~mm} \mathrm{MgCl}, 3 \mathrm{~mm}$ $\mathrm{K}_{4}\left[\mathrm{FeII}(\mathrm{CN})_{6}\right], 3 \mathrm{mM} \mathrm{K}_{3}\left[\mathrm{FeIII}(\mathrm{CN})_{6}\right]$ containing a 1:50 dilution of $\mathrm{X}$-GAL $(25 \mathrm{mg} / \mathrm{ml}$ in dimethyl formamide). Ovaries were stained at room temperature for periods ranging from $1 \mathrm{hr}$ to overnight. After washing in PBS, $0.1 \%$ Triton X-100, ovaries were mounted in $70 \%$ glycerol. 


\section{Mounting eggs and cuticles}

Eggs were mounted in a 1:1 mixture of Hoyer's mountant and lactic acid, and then cleared overnight on a hot plate at $65^{\circ} \mathrm{C}$. To highlight the follicle cell imprints, chorions were photographed using a 10X phase contrast objective with the condenser set to the phase 3 position. Follicle cell imprints were counted on an enlarged photograph showing a lateral view of each chorion. The counts are, therefore, very approximate, and are not comparable to those given by Schupbach (1987).

Cuticles were prepared and mounted as described by Struhl (1989).

\section{Epistasis experiments}

Eggs laid by females homozygous for the EGF receptor mutation $t o p^{1}$ were compared with eggs laid by top ${ }^{1}$ females expressing Raf ${ }^{\text {gof }}$. The GAL4 system was used to express either $U A S-D r a f^{g o f}$ (in females of the genotype top $1 /$ top $^{1}$; $p G a w B^{5 S B}$ / $U A S-\triangle D$ raf $^{F 179}$ ) or UAS-human rafgof (in females of the genotype UAS- $\Delta c R a f 1^{r a 2} /+$; top $p^{1} /$ top $^{1} ; p G a w B^{55 B} /+$ and UAS $\Delta$ CRaf $1^{\text {ra2 }} /+$; top ${ }^{1} /$ top $^{C l}$; $p G a w B^{55 B} /+$; see Fig. 7, C and D).

\section{Acknowledgments}

We thank Joe Duffy for discussions throughout the course of this work, for communicating results before publication, and for comments on the manuscipt. We are most grateful to Trudi Schupbach for providing numerous stocks, including her unpublished line AN296, and for helpful discussions. Thanks go to Daniel St. Johnston for his drawing of the stage 10 egg chamber shown in Figure 7, and to Beth Noll for developing and printing most of the black-and-white photographs. We thank Xiangyi Lu, Eric Wieschaus, Linda Ambrosio, Nidhi Williams, Carl Thummel, and Vincent Pirrotta for providing Drosophila strains or DNAs, and Trudi Schupbach, Dennis McKearin, Xiangyi Lu, Tze-Bin Chou, and Liz Perkins for communicating results before publication. Many thanks to Daniel St. Johnston, Acaimo Gonzales-Reyes, Jonathon Pines, and Jim Haseloff for comments on the manuscript. A.B. was supported by postdoctoral fellowships from the Helen Hay Whitney Foundation and the National Institutes of Health, and by a Leukemia Society of America Special Fellowship. This work was supported by the Howard Hughes Medical Institute.

The publication costs of this article were defrayed in part by payment of page charges. This article must therefore be hereby marked "advertisement" in accordance with 18 USC section 1734 solely to indicate this fact.

\section{References}

Ambrosio, L., A.P. Mahowald, and N. Perrimon. 1989a. I(1) pole hole is required maternally for pattern formation in the terminal regions of the embryo. Development 106: 145-158.

- $1989 \mathrm{~b}$. Requirement of the Drosophila raf homologue for torso function. Nature 342: 288-291.

Anderson, K.V., G. Jurgens, and C. Nusslein-Volhard. 1985. Establishment of dorsal-ventral polarity in the Drosophila embryo: Genetic studies on the role of Toll gene product. Cell 42: 779-789.

Aroian, R.V., M. Koga, J.E. Mendel, Y. Ohshima, and P.W. Sternberg. 1990. The let-23 gene necessary for C. elegans vulval induction encodes a tyrosine kinase of the EGF receptor subfamily. Nature 348: 693-699.

Beitel, G.J., S.G. Clark, and H.R. Horvitz. 1990. Caenorhabitis elegans ras gene let-60 acts as a switch in the pathway of vulval induction. Nature 348: 503-509.

Bier, E., H. Vaessin, S. Shepherd, K. Lee, K. McCall, S. Barbel, L. Ackerman, R. Carretto, T. Uemura, E. Grell, L.Y. Jan, and Y.N. Jan. 1989. Searching for pattern and mutation in the Drosophila genome with a P-lacZ vector. Genes \& Dev. 3: $1273-1287$.

Biggs, W.H. and S.L. Zipursky. 1992. Primary structure, expression, and signal-dependent tyrosine phosphorylation of a Drosophila homolog of extracellular signal-regulated kinase. Proc. Natl. Acad. Sci. 89: 6295-6299.

Brand, A.H. and N. Perrimon. 1993. Targeted gene expression as a means of altering cell fates and generating dominant phenotypes. Development 118: 401-415.

Bruder, J.T., G. Heidecker, and U.R. Rapp. 1992. Serum- , TPA, and Ras-induced expression from Ap-1/Ets-driven promoters requires Raf-1 kinase. Genes \& Dev. 6: 545-556.

Casanova, J. and G. Struhl. 1989. Localized surface activity of torso, a receptor tyrosine kinase, specifies terminal body pattern in Drosophila. Genes \& Dev. 3: 2025-2038.

Chasan, R., Y. Jin, and K.V. Anderson. 1992. Activation of the easter zymogen is regulated by five other genes to define dorsal-ventral polarity in the Drosophila embryo. Development 115: 607-616.

Chou, T.-B., E. Noll, and N. Perrimon. 1993. Autosomal Plov. $o^{D i}$ d dominant female sterile insertions in Drosophila and their use in generating germ-line chimeras. Development 119: 1359-1369.

Clifford, R.C. and T. Schupbach. 1989. Coordinately and differentially mutable activities of torpedo, the Drosophila melanogaster homolog of the vertebrate EGF receptor gene. Genetics 123: 771-787.

Dickson, B., F. Sprenger, D. Morrison, and E. Hafen. 1992. Raf functions downstream of Ras 1 in the Sevenless signal transduction pathway. Nature 360: 600-603.

Doyle, H.J. and J.M. Bishop. 1993. Torso, a receptor tyrosine kinase required for embryonic pattern formation, shares substrates with the Sevenless and EGF-R pathways in Drosophila. Development 7: 633-646.

Fortini, M.E., M.A. Simon, and G.M. Rubin. 1992. Signalling by the sevenless protein tyrosine kinase is mimicked by Ras 1 activation. Nature 355: 559-561.

Gaul, U., G. Mardon, and G.M. Rubin. 1992. A putative ras GTPase activating protein acts as a negative regulator of signaling by the sevenless receptor tyrosine kinase. Cell 68: 1007-1019.

Han, M. and P.W. Sternberg. 1990. let-60, a gene that specifies cell fates during $C$. elegans vulval induction, encodes a ras protein. Cell 63: 921-931.

Han, M., A. Golden, Y. Han, and P.W. Sternberg. 1993. C. elegans lin-45 raf gene participates in let- 60 ras-stimulated vulval differentiation. Nature 363: 133-140.

Hashimoto, C., K.L. Hudson, and K.V. Anderson. 1988. The Toll gene of Drosophila, required for dorsal-ventral embryonic polarity, appears to encode a transmembrane protein. Cell 52: 269-279.

Hashimoto, C., S. Gerttula, and K.V. Anderson. 1991. Plasma membrane localization of the Toll protein in the syncytial Drosophila embryo: Importance of transmembrane signaling for dorsal-ventral pattern formation. Development 111: 1021-1028.

Heidecker, G., W. Kolch, D.K. Morrison, and U.R. Rapp. 1992. The role of Raf-1 phosphorylation in signal transduction. Adv. Cancer Res. 58: 53-73.

Kelley, R.L. 1993. Initial organization of the Drosophila dorsoventral axis depends on an RNA-binding protein encoded 
by the squid gene. Genes \& Dev. 7: 948-960.

King, R.C. 1970. Ovarian development in Drosophila melanogaster. Academic Press, New York.

Kramers, P.G.N., A.P. Schalet, E. Paradi, and L. HuiserHoogteyling. 1983. High proportion of multi-locus deletions among hycanthone-induced X-linked recessive lethals in Drosophila melanogáster. Mutat. Res. 107: 187-201.

Lindsley, D.L. and G.G. Zimm. 1992. The genome of Drosophila melanogaster. Academic Press, New York.

Lu, X., T.-B. Chou, N.G. Williams, T. Roberts, and N. Perrimon. 1993. Control of cell fate determination by $21^{\text {ras }} /$ Ras 1 , an essential component of torso signaling in Drosophila. Genes \& Dev. 7: 621-632.

Mahowald, A.P. and M.P. Kambysellis. 1980. Oogenesis. In The genetics and biology of Drosophila, Vol. 2 (ed. M. Ashburner and T.R.F. Wright), pp. 141-224. Academic Press, London.

Manseau, L.J. and T. Schupbach. 1989. cappuccino and spire: Two unique maternal effect loci required for both the anteroposterior and dorsoventral patterns of the Drosophila embryo. Genes \& Dev. 3: 1437-1452.

Melnick, M.B., L.A. Perkins, M. Lee, L. Ambrosio, and N. Perrimon. 1993. Developmental and molecular characterization of mutations in the Drosophila-raf serine/threonine protein kinase. Development 118: 127-138.

Morrison, D.K., D.R. Kaplan, U.R. Rapp, and T.M. Roberts. 1988. Signal transduction from membrane to cytoplasm: Growth factors and membrane-bound oncogene products increase Raf- 1 phosphorylation and associated protein kinase activity. Proc. Natl. Acad. Sci. 85: 8855-8859.

Neuman-Silberberg, F.S. and T. Schupbach. 1993. The Drosophila dorsoventral patterning gene gurken produces a dorsally localized RNA and encodes a TGF $\alpha$-like protein. Cell 75: 165-174.

Nishida, Y., M. Hata, T. Ayaki, H. Ryo, M. Yamagata, K. Shimizu, and Y. Nishizuka. 1988. Proliferation of both somatic and germ cells is affected in the Drosophila mutants of raf proto-oncogene. EMBO I. 7: 775-781.

Perkins, L.A., I. Larsen, and N. Perrimon. 1992. corkscrew encodes a putative protein tyrosine phosphatase that functions to transduce the terminal signal from the receptor tyrosine kinase torso. Cell 70: 225-236.

Perrimon, N., L. Engstrom, and A.P. Mahowald. 1985. A pupal lethal mutation with a paternally influenced maternal effect on embryonic development in Drosophila melanogaster. Dev. Biol. 110: 480-491.

Price, J.V., R.J. Clifford, and T. Schupbach. 1989. The maternal ventralizing locus torpedo is allelic to faint little ball, an embryonic lethal, and encodes the Drosophila EGF receptor homolog. Cell 56: 1085-1092.

Prost, E., F. Deryckere, C. Roos, M. Haenlin, V. Pantesco, and E. Mohier. 1988. Role of the oocyte nucleus in determination of the dorsoventral polarity of Drosophila as revealed by molecular analysis of the $K 10$ gene. Genes \& Dev. 2: 891-900.

Robertson, H.M., C.R. Preston, R.W. Phillis, D. JohnsonSchlitz, W.K. Benz, and W.R. Engels. 1988. A stable source of P-element transposase in Drosophila melanogaster. Genetics 118: 461-470.

Rogge, R.D., C.A. Karlovich, and U. Banerjee. 1991. Genetic dissection of a neurodevelopmental pathway: Son of sevenless functions downstream of the sevenless and EGF receptor tyrosine kinases. Cell 64: 39-48.

Ruohola-Baker, H., E. Grell, T.-B. Chou, D. Baker, L.Y. Jan, and Y.N. Jan. 1993. Spatially localized rhomboid is required for establishment of the dorsal-ventral axis in Drosophila oogenesis. Cell 73: 953-965.

Schejter, E.D. and B.-Z. Shilo. 1989. The Drosophila EGF recep- tor homologue (DER) is allelic to faint little ball, a locus essential for embryonic development. Cell 46: 1091-1101.

Schupbach, T. 1987. Germ line and soma cooperate during oogenesis to establish the dorsoventral pattern of egg shell and embryo in Drosophila melanogaster. Cell 49: 699-707.

Schupbach, T., R.J. Clifford, L.J. Manseau, and J.V. Price. 1991. Dorsoventral signaling processes in Drosophila oogenesis. In Cell-cell interactions in early development (ed. J. Gerhart), pp. 163-1174. Wiley-Liss, New York.

Simon, M.A., D.D. Bowtell, G.S. Dodson, T.R. Laverty, and G.M. Rubin. 1991. Ras1 and a pupative guanine nucleotide exchange factor perform crucial steps in signaling by the sevenless protein tyrosine kinase. Cell 67: 701-716.

Spradling, A. 1986. P element-mediated transformation. In Drosophila, a practical approach (ed. D.B. Roberts), pp. 175198. IRL Press, New York.

Stanton, V.J., D.W. Nichols, A.P. Laudano, and G.M. Cooper. 1989. Definition of the human raf amino-terminal regulatory region by deletion mutagenesis. Mol. Cell Biol. 9: 639647.

Stein, D. and C. Nüsslein-Volhard. 1992. Multiple extracellular activities in Drosophila egg perivitelline fluid are required for establishment of embryonic dorsal-ventral polarity. Cell 68: 429-440.

Stein, D., S. Roth, E. Vogelsang, and C. Nüsslein-Volhard. 1991. An activity present in the perivitelline space of the Drosophila egg determines the dorsoventral axis of the embryo. Cell 65: 725-735.

Struhl, G. 1989. Morphogen gradients and the control of body pattern in insect embryos. Ciba Found. Symp. 144: 65-86.

Thummel, C.S. and V. Pirotta. 1992. New pCaSpeR P element vectors. Drosophila Inf. Serv. 71: 150.

Tsuda, L., Y.H. Inoue, M.A. Yoo, M. Mizuno, M. Hata, Y.M. Lim, Y.T. Adachi, H. Ryo, Y. Masamune, and Y. Nishida. 1993. A protein kinase similar to MAP kinase activator acts downstream of the raf kinase in Drosophila. Cell 72: 407414.

Vojtek, A.B., S.M. Hollenberg, and J.A. Cooper. 1993. Mammalian Ras interacts directly with the serine/threonine kinase Raf. Cell 74: 205-214.

Warne, P.H., P. Rodriguez Viciana, and J. Downward. 1993. Direct interaction of Ras and the amino-terminal region of Raf-1 in vitro. Nature 364: 352-355.

Wasylyk, C., B. Wasylyk, G. Heidecker, M. Huleihel, and U.R. Rapp. 1989. Expression of raf oncogenes activates the PEAl transcription factor motif. Mol. Cell Biol. 9: 2247-2250.

Wieschaus, E. 1979. $f_{S}(1) K 10$, a female sterile mutation altering the pattern of both egg coverings and the resultant embryos in Drosophila. INSERM Symp. 10: 291-302.

Wieschaus, E., J.L. Marsh, and W.J. Gehring. 1978. fs(1)K10, a germ-line dependent female-sterile mutation causing abnormal chorion morphology in Drosophila melanogaster. Wilhelm Roux's Arch. Dev. Biol. 184: 75-82.

Zhang, X.-f., J. Settlemen, J.M. Kyriakis, E. Takeuchi-Suzuki, S.J. Elledge, M.S. Marshall, J.T. Bruder, U.R. Rapp, and J. Avruch. 1993. Normal and oncogenic p2l ras proteins bind to the amino-terminal regulatory domain of c-Raf-1. Nature 364: 308-313. 


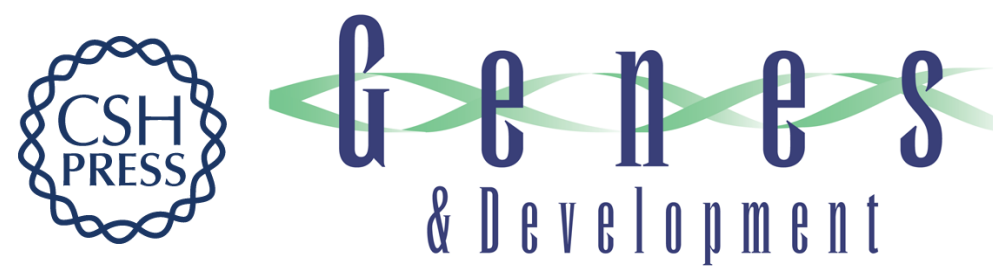

\section{Raf acts downstream of the EGF receptor to determine dorsoventral polarity during Drosophila oogenesis.}

A H Brand and N Perrimon

Genes Dev. 1994, 8:

Access the most recent version at doi:10.1101/gad.8.5.629

References This article cites 52 articles, 19 of which can be accessed free at:

http://genesdev.cshlp.org/content/8/5/629.full.html\#ref-list-1

License

Email Alerting

Service

Receive free email alerts when new articles cite this article - sign up in the box at the top right corner of the article or click here.

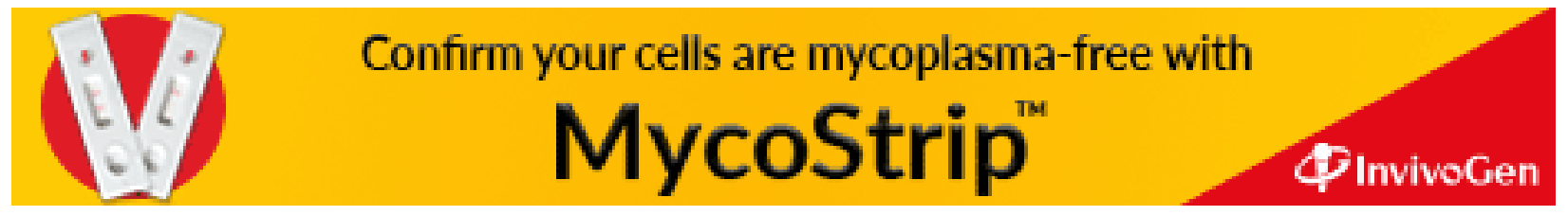

